\title{
THE HISTORICAL ASPECTS OF VENOUS THROMBOSIS*
}

\author{
BY \\ S. T. ANNING, M.A., M.D., M.R.C.P. \\ Consultant Dermatologist, The General Infirmary at Leeds
}

THE history of venous thrombosis illustrates in miniature the development of the history of medicine itself, but here only a few aspects can be considered. The history of our knowledge concerning coagulation of the blood alone is such a large subject that it can only be touched upon and, in reference to venous thrombosis, we shall merely deal with phlegmasia dolens occurring in the lower limb.

I have sought to answer two questions. As regards the first, which is pathological: Virchow's triad of factors concerned with venous thrombosis, namely lesions of the vascular intima, changes in the velocity of the bloodstream and alterations in the constitution of the blood, still forms a useful basis for consideration of the aetiology of this condition. What led to the formulation of this concept?

The second question deals with the clinical aspects. Venous thrombosis in deep veins, especially as exemplified by phlegmasia dolens occurring post-partum, is such a distinct entity that clear references to it might be expected in the works of early medical writers. The painful swelling of the lower limb appearing suddenly during the first two or three weeks after delivery could scarcely escape the attention of the mother, her midwife, her physician or her relatives. Yet, in point of fact, references to it before the eighteenth century are rare. What are the reasons for this?

Huang $\mathrm{Ti}$, about $265^{\circ}$ B.c., wrote that 'when it coagulates within the pulse the blood ceases to circulate beneficially; when the blood coagulates within the foot it causes pains and chills' (Veith, 1949). This, of course, may refer to arterial thrombosis. In searching for an early European description of venous thrombosis we must obviously consult the Hippocratic school, but here we meet with very limited success. Several detailed accounts are given of patients with puerperal fever and the limbs are mentioned as being cold, livid and painful but, curiously, never as swollen. However, some of the patients had died a few days after labour.

Hippocrates used the term 'leucophlegmatia' on several occasions (Adams, I849; Chadwick and Mann, I950). From his writings and those of later authors such as Aretaeus the Cappadocian (Adams, I856), Paulus

* An address to the Cambridge University History of Medicine Society on 1o May 1956. 


\section{The Historical Aspects of Venous Thrombosis}

Aegineta (Adams, I844-47) and Caelius Aurelianus who translated the works of Soranus of Ephesus, it seems that this term was used for a variety of conditions associated with oedema, especially renal disease, cardiac failure, cirrhosis of the liver and lymphatic obstruction. Caelius Aurelianus mentions suppression of the menses as a cause (Drabkin, 1950). It seems probable that post-thrombotic oedema of the legs must sometimes have been referred to as leucophlegmatia. In the fourth book of the Epidemics, not now accepted as part of the genuine Hippocratic body of writing, we read that: 'Thersander's wife who suckled her own child, being troubled with a leucophlegmatia, or a sort of dropsy though not to a great degree, was seized with an acute fever' (Ramazzini, I 705). Might she not have had puerperal fever and phlegmasia dolens? Perhaps nephritis is more likely.

Of phlegmasia dolens we learn nothing from Aristotle, but he made some remarkable observations about coagulation of the blood. He believed it to result from the presence of fibrous material, though it is not certain whether he considered this to be in the blood in liquid form, becoming fibrous on clotting, or present in its fibrous state the whole time. He made it clear that 'if this fibre be left in the blood, the blood will coagulate; if it be removed or extracted, the blood is found to be incapable of coagulation' (Thompson, 1910). This would suggest that by two thousand years he anticipated Ruysch's discovery, made about I 700, that the fibrous matter could be removed from fresh blood by agitating it with a twig, thus preventing clotting (Ruysch, I707).

From the Graeco-Roman medical writers we learn little about our subject. Galen introduced the term 'thrombosis', Greek for curdling, and Shakespeare obviously had this in mind when he wrote:

\section{... Whose effect}

Holds such an enmity with blood of man,

That ... with a sudden vigour, it doth posset

And curd, like eager droppings into milk,

The thin and wholesome blood.

Hamlet, I. v. 65.

Paulus Aegineta, writing on inflammation of the uterus, mentioned 'tightness of the groins and heaviness of the limbs' (Adams, 1844-47), but other authors of this period, including Aetius of Amida who wrote about obstetrics, have not, as far as I can discover, made reference to any condition resembling phlegmasia dolens.

However, in one of the Consilia of Ugo Benzi of Sienna, written about I400 (Lockwood, I95I), we find a description of venous thrombosis occurring during a long illness. 


\section{S. T. Anning}

The excellent man, Master Jacobus Manni of Novara, suffered from fevers with emaciation of the body and apparently complete loss of appetite from the beginning of February last for many months. During this period his legs began to swell and, although his appetite returned and the fever receded, the swelling, which was an oedema as from blood-letting, occupying the legs and hips, persisted.

The mention of oedema 'as from blood-letting' is interesting. Ankle veins and those on the instep were often used in phlebotomy and infection followed by thrombophlebitis and swelling of the legs is sometimes seen nowadays after transfusions into veins at the ankle.

Medical thought was dominated for fifteen centuries or more by Galen's theory of humours, based on the writings of Hippocrates and earlier writers, and by his idea of the to-and-fro movement of blood containing various spirits. Henri de Mondeville wrote about 1320 of harmful humours infiltrating the leg (Nicaise, I893) and Jean Fernel of Paris, 200 years later, referred to oedematous ulcers of the legs caused by the collection of corrupt humours (Fernel, I 577). In I 596 Peter Lowe, who described himself on his title-page as 'Scottishman', believed, like the Graeco-Roman authors, that these were cold humours (Lowe, 1612) and another Briton, Thomas Vicary, who died in $156 \mathrm{I}$, had noted that 'the Legges ... when they are offended or wounded, are very perillous, because unto them runneth a great quantity of humors' (Vicary, 1636). According to Ambroise Paré, a contemporary of Fernel, varicose veins and swelling of the legs occurred in pregnant women 'by reason of the heaping together of their suppressed menstruall evacuation' (Johnson, 1678 ). The idea that menstrual blood is an evil humour persisted, and Astruc $(176 \mathrm{I}-65)$ seems to have been the first clearly to deny this.

Similarly, until the end of the eighteenth century, post-partum venous thrombosis was explained in terms of the humoral theory. Widely held was the view that the lochia were bad humours whose retention, often occurring during puerperal fever, was likely to cause trouble. In I604 Roderiguez a Castro of Hamburg published his work De Universa Mulierum Morborum Medicina. He not only considered the swollen and livid legs of pregnant women, but was interested in swelling of the lower extremities in the puerperium. 'We observe,' he wrote, 'swelling of the legs to occur after childbirth when the lochia flow less copiously.' He thought that immoderate drinking after child-birth precipitated the trouble and made the important observation that it might also follow excessive bleeding.

François Mauriceau of Paris, writing in 1668 , also took the view that suppression of the lochia caused swelling of the legs brought about by metastasis of the lochia or, to use his own words, 'to a reflux determined to those parts [i.e. the lower extremities] of humours, which ought to be evacuated by the lochia' (Mauriceau, 1712). He had seen many women delivered whose legs became wholly oedematous and extraordinarily 


\section{The Historical Aspects of Venous Thrombosis}

swollen, and he mentioned one of his aunts who for thirty-eight years had suffered from a swollen leg, the condition having appeared suddenly after one of her confinements. Suppression of the lochia was thought by Mesnard ( 1753 ) to cause 'an over fulness of the blood vessels, and a consequent arrest and coagulation of lymph in the parts affected'.

In this country the condition had been described in 1676 by Richard Wiseman, Sergeant-Chirurgeon to Charles II. In a chapter on 'Abscesses and Corrosive Ulcers arising from Distempers of the Uterus in Child-bed' he relates the following history:-

An Apothecary's wife, living in my Neighbourhood in the Old Bailey, after a hard Child-bed labour was seized with a Fever, and great pain in her right Thigh, from the Groin and Hip downward to the Knee, swelling the Member round, without inflammation or discolouring the Skin.

Wiseman did not speculate about the cause of the condition though he was familiar with venous thrombosis for, on the subject of varix, he had written:

It proceedeth from the restagnation of gross Blood, which being transmitted into the Veins, either by reason of the depending of the Part, or from some other pressure upon the Vessel, or else by its own grossness, proves unapt for Circulation. Then, instead of continuing its current proportionably to the other Parts, it stops in the place and coagulates, and by degrees encreaseth itself by the accession of the like particles out of the succeeding Blood. ... This coagulation of Blood in a Varix, is not so entire as to stop the passage wholly.

Wiseman would almost certainly have read the works of Ambroise Paré who, a hundred years previously, had clearly recognized the presence of thrombophlebitis in a superficial varicose vein when he wrote: 'They often swell with congealed and dryed bloud, and cause pain which is increased by going and compression' (Johnson, 1678).

Before returning to the subject of post-partum phlegmasia we must briefly consider what advances had been made in the pathology of coagulation. About 1674 Leeuwenhoek (Hoole, I80o; Dobell, I932) accurately described and measured the red blood corpuscles previously seen by Swammerdam in 1658 (Major, 1954) and thought by Malpighi in 1666 to be fat globules. Boerhaave ( 1740 ) and Haller ( I 786) believed coagulation to be a mere conjunction of red blood corpuscles, though Malpighi had already washed the red matter from clot and found the white fibrous part. Haller took the view, very like that of Aristotle, that coagulation resulted from loss of the innate heat generated by the red cells. He also supported the humoral theory, believing that the constitution of the blood varied according to the temperament of the individual. Haller, nevertheless, made an 


\section{S. T. Anning}

observation of considerable importance in relation to our subject; that oedema of a limb follows obstruction of the veins either by ligation or pressure upon them.

Puzos ( I 759) died in I 753, but had put forward a new theory, which owed much to the idea of humours, to explain post-partum phlegmasia dolens. He considered that milk is formed in women during pregnancy, as well as after delivery, and is directed principally to the uterus in the former, and to the breasts later. When the foetus in utero or the infant at the breast cannot consume the whole of the milk that is formed, the excess escapes in the excretions or collects in certain parts of the body and particularly in the lower limbs. Levret ( 1766 ) also supported the theory of 'engorgemens laiteux' in the lower extremities, pointing out that they rarely appear before the twelfth or fifteenth day of lying-in and that milk fever is present. Astruc ( $176 \mathrm{I}-65$ ) discussed 'dépôts de lait' and De Sauvages in his Nosologia Methodica used the term 'phlegmatia lactea' (1768). Even nowadays one occasionally hears the expression 'milk leg'.

We have seen that the humoral theory still exerted an influence on medical thought in the eighteenth century. Nevertheless, a fundamental blow to the theory had been struck when Harvey in 1628 announced his demonstration of the circulation of the blood. You will recollect that he reached his conclusions after studying the valves in veins, appreciating that, in a vessel containing valves, a to-and-fro movement of blood is not possible.

Moreover, as you are well aware, the seventeenth century saw a revolution in scientific thought: deduction took the place of induction, observation that of theorizing. In medicine this led to the iatro-physical or iatro-mechanical theory originating in Italy with Sanctorius Sanctorius of Padua, Borelli of Pisa and Baglivi of Rome but owing much to Descartes. In Brussels Van Helmont founded the iatro-chemical school. Probably influenced by Newton's Principia of 1687 and by Morgan's book on The Philosophical Principles of Medicine (1725), which was based on it, there were in this country many adherents to the iatro-mechanical doctrines which viewed the body as a machine with pumps, tubes and valves, and with levers of bones and joints activated by muscles. For example, Quincy in 1722 in the preface to his Lexicon Physicomedicum wrote: 'And because what is brought from Physicks and Mechanicks takes up so much room here, it may be necessary to inform the Reader, that there is no Knowledge in Medicine but by such means'.

The iatro-mechanical theory had its influence on our present subject. In I 708 Pierre Dionis of Paris attributed the varicose veins of pregnant women to the pressure of the uterus on the iliac veins, and Charles White ( 1784 ) believed post-partum phlegmasia also to have a mechanical cause. White, who was 'man-midwife extraordinary to the Manchester Lying-in 


\section{The Historical Aspects of Venous Thrombosis}

Hospital', published a tract on the swelling in one or both of the lower extremities during the puerperium. He wrote that it was 'not owing to any defect of the lochia as it happens to those who have the most regular discharge, nor to a deposit of milk as it happens under every circumstance attending that secretion. The proximate cause of this disorder, he thought, 'is an obstruction, detention and accumulation of lymph in the limb' brought about by rupture of the lymphatics from pressure of the 'foetus's head' during labour, and he did not believe that it occurred under conditions other than parturition.

Trye of Gloucester (I 792) criticized White's views and said that, although he could not discover any grounds for supposing the trunk of the lymphatics to be ruptured in labour, 'yet he could easily conceive that the obstruction to the return of the lymph may commence in the primary inflammation of a trunk or trunks'. He made the observation that the condition is usually preceded by puerperal fever, and that 'the complaint has rarely come on before the end of the second, or the beginning of the third week after delivery'.

John Hunter (i 793) first put forward the view that primary phlebitis led to clotting and plugging of the vein, and in the same year his nephew, Matthew Baillie, emphasized the importance of slowing of the blood-stream as a cause of thrombosis. Meanwhile, Hunter's brilliant assistant, William Hewson, who died in 1774 at the age of thirty-five, had carried out important work on the coagulation of blood. He established the fact that it is due, not to a conjunction of corpuscles but to 'coagulable lymph' in the plasma, a substance later called fibrinogen. He noted that living tissues retard coagulation. He also observed that when coagulation of blood occurs in the veins of the lower limb oedema results (Hewson, I846).

This period of medical history marks the beginning of what may be called the patho-physiological approach to medicine, and it is noteworthy that in 1805 Jones, referring to bleeding from divided arteries, wrote: 'We can no longer consider the suppression of hemorrhage as a simple or mere mechanical effect'.

In I800 a Manchester surgeon named Hull reviewed the literature on what he named 'phlegmatia dolens' and advanced the theory that it was brought about by inflammation of the muscles and skin, with consequent coagulation of lymph. The term 'phlegmatia alba dolens puerperarium' was first used in the following year by White and in 18 ro Ferrier pointed out that the condition was not exclusively puerperal but also occurred after typhus fever. Five years later Hodgson (1815) noted that injury to a vein might cause thrombosis which sometimes extended into the principal venous trunks, and in I829 Hutchinson described how a Mr. B. had suffered from phlegmasia dolens following a blow on the shin from a piece of timber. 


\section{S. T. Anning}

However, Davis of Queen Charlotte's Hospital was the first clearly to appreciate that in post-partum phlegmasia dolens the veins are the seat of the trouble. He published in 1822 a paper on 'The Proximate Cause of Phlegmasia Dolens' which he showed to result from a 'violent inflammation of one or more of the principle veins within and in the immediate neighbourhood of the pelvis' with a 'gradual coagulation of their contents . . . in consequence of which, the diameters of the cavities of these important vessels become so greatly diminished, sometimes so totally obstructed as to be rendered mechanically incompetent to carry forward into their corresponding trunks the venous blood brought to them by their inferior contributory branches'.

Lee (1829a) agreed that inflammation of the coats of the iliac and femoral veins results in thrombosis, and he demonstrated that the disease begins in the uterine veins as a phlebitis, extending thence to the iliac and femoral veins. In 1853 he showed the relationship of the condition to complicated labour with intra-uterine manipulation and about the same time Cruveilhier (1829-55) wrote of 'phlébite traumatique puerpérale'. Nevertheless, the venous theory of the cause of phlegmasia dolens was not for a time generally accepted. Dewees (1829) strongly disagreed with Davis, although as he wrote he was 'not prepared to say what the exciting cause is'. Shortly after, Sir Charles Bell (1838) confessed that to him the subject was still obscure, and said, referring to Davis and Lee, that 'our experienced and acute Professor of Midwifery says they are confounding two distinct casesphlegmasia dolens and crural phlebitis'.

However, during the next few decades much was done to elucidate the pathology of this condition. In 1852 Rokitansky differentiated two types of venous thrombosis: on the one hand that resulting from phlebitis caused by injury to the vein or inflammation in its neighbourhood, and on the other thrombosis arising as a primary condition from changes in the blood itself. It came to be appreciated, for example, that changes occurred after haemorrhage making the blood coagulate more readily, an observation consistent with Roderiguez a Castro's view in 1604 that swelling of the legs after child-birth occurred more commonly when there had been excessive bleeding. Hayem ( 1889 ) was the first to recognize the role played by the platelets in thrombosis.

While these and other pathological observations, including those of Virchow, were being made the aetiology of the condition was rousing the interest of clinicians. A full clinical account of post-partum thrombosis was published by MacKenzie (1853). He found it to be most common after the first or second confinement, and related this to 'the more protracted parturient efforts, the greater injury to the soft parts, and the more considerable reaction which must occur in these than subsequent labours'. 


\section{The Historical Aspects of Venous Thrombosis}

More recent studies have confirmed his findings-the condition is more common after difficult labour, especially when there has been instrumental delivery, puerperal sepsis or haemorrhage. These, together with the slowing of the venous blood flow in the legs, the result both of lying in bed and of parturition itself, illustrate well Virchow's triad of factors.

To say that post-partum thrombosis does not occur if the mother dies in child-birth is to state the obvious, yet this may well be the reason for the paucity of references to the condition before the seventeenth century. Previously a woman whose confinement was abnormal was likely to die from haemorrhage, infection, obstructed labour or from the treatment she received. Midwives were almost invariably employed, but very few of them wrote about their experiences-another reason for lack of references during this period. Nevertheless, even Ambroise Paré, who practised obstetrics and wrote on the subject in the sixteenth century, did not mention post-partum swelling of the legs (Johnson, 1678 ).

It is probable that the invention of forceps and the appearance of reports of phlegmasia dolens, which occurred about the same time, were not unconnected. Obstetric forceps were invented by Peter Chamberlen, an Huguenot refugee, about 1600 , but the invention was held as a secret by his family for about 120 years. The steel lock forceps were introduced in I 744 by William Smellie who, incidentally, seems to have been the first to describe ante-partum phlegmasia dolens ( 1764 ). By the mid-eighteenth century forceps appear to have been in general use, and it was during this time that the care of women in labour began to pass from the midwife to the male obstetrician. No doubt the use of forceps saved many lives, but in doing so made phlegmasia dolens more common. A similar state of affairs has occurred more recently following the introduction of antibiotics (McSweeney, 1949). As the death-rate from puerperal fever has been reduced so has the incidence of post-partum thrombosis risen.

\section{SUMMARY}

The historical aspects of venous thrombosis have been considered with particular reference to the development of the concept of Virchow's triad, and to the paucity of reports of the condition in early medical writings.

I am greatly indebted to Dr. F. N. L. Poynter and Mr. H. R. Denham of the Wellcome Historical Medical Library for access to several rare editions. The latter kindly translated the extract from Ugo Benzi. 


\section{S. T. Anning}

\section{REFERENGES}

Ad ams, F. (1844-47), The Seven Books of Paulus Aegineta. London, Sydenham Soc.

- (1849). The Genuine Works of Hippocrates. London, Sydenham Soc.

- (1856). The Extant Works of Aretaeus, the Cappadocian. London, Sydenham Soc.

Astruc, J. ( $176 \mathrm{I}-65)$. Traité de Maladies des Femmes. 6 vols. Paris, Cavelier.

BAILlIE, M. (I 793). 'Of uncommon appearances of disease in blood-vessels.' Trans. Soc. Improv. Med. Chir. Knowledge, I, I 19.

BE L L, C. (1838). Institutes of Surgery, Vol. II. Edinburgh, Black.

Bor rhaAve, H. (1740). Praelectiones academicae in proprias institutiones rei medicae. Ed. et notas add. A. Haller. Vol. II. S. ccxxvii. Gottingae, Vandenboeck.

Gastro, Roderiguez a (1604). De universa mulierum morborum medicina. Hamburg, Frobeniana.

Gradwick, J., and Mann, W. N. (1950). The Medical Works of Hippocrates. Oxford, Blackwell.

Gruveilhier, J. (1829-55). Anatomie pathologique du corps humain. 2 vols. Paris, Baillière.

Davis, D. D. (1822). 'The Proximate Cause of Phlegmasia Dolens.' Med. chir. Trans., xIr, 419.

Dewees, W. P. (1829). 'On Phlegmasia Dolens.' Amer. J. med. Sci., v, 66.

Dron Is, P. (1 708). Cours d'opérations de chirurgie. Brussels, Les frères t'Serstevens et Claudinot.

Dове L , C. (1932). Antony van Leeuwenhoek and His 'Little Animals'! London, Bale and Danielson.

Drab Kin, I. E. (1950). Ed. and trans. Caelius Aurelianus On Acute Diseases and on Chronic Diseases. Chicago, Univ Press.

Ferne L, J . (1577). Universa Medicina. Lib. vii. Frankfort, Wechel.

FerRiar, J. (1810). 'An affectation of the Lymphatic vessels hitherto misunderstood.' Medical Histories and Reflections, Vol. III.

Halle R, A. (1 786). First Lines of Physiology. Trans. W. Cullen. Edinburgh, Elliot.

Harvey, W. (1628). Exercitatio anatomica de motu cordis. Ed. G. Keynes, 1928. London, Nonesuch Press.

HA Y E M, G. (1889). Du sang et des altérations anatomiques. Paris, Masson.

Hewson, W. (1846). The Works of William Hewson, F.R.S. Ed. G. Gulliver. London, Sydenham Soc.

Hodgson, J. (1815). A Treatise on the Diseases of Arteries and Veins. London, Underwood.

Hoole, S. (1800). The Select Works of Antony Van Leeuwenhoek. London, Sidney.

Hul L, J. (1800). Essay on Phlegmasia Dolens. Manchester, Dean.

HunteR, J. (I 793). 'Observations on the inflammation of the internal coats of veins.' Trans. Soc. Improv. Med. Chir. Knowledge, I, 18.

Hutchinson, A. G. (1829). In Lee, R. 'Pathological researches on inflammation of the veins of the uterus with additional observations on phlegmasia dolens.' Med. chir. Trans., Xv, 425 .

Johnson, T. (1678). The Works of that Famous Chirurgeon, Ambrose Parey. London, Clark.

Jones, J. F. D. (1805). A treatise on the Process Employed by Nature in Suppressing the Hemorrhage from Divided and Punctured Arteries; and on the Use of the Ligature; etc. London, Phillips.

LeE, R. (I829a). 'A Contribution to the pathology of phlegmasia dolens.' Med. chir. Trans., $\mathrm{XV}, \mathrm{I} 32$.

- (1829b). 'Pathological Researches on Inflammation of the Veins of the Uterus.' Ibid., $\mathrm{xv}, 369$.

- (1853). 'The Pathology of Phlegmasia Dolens,' Ibid., xxxvı, 282. 


\section{The Historical Aspects of Venous Thrombosis}

Levret, A. (1 766). L'Art des Accouchemens. 3rd ed. Paris, Didot.

Lockwood, D. P. (1951). Ugo Benzi: Medieval Philosopher and Physician, 1376-1439. Chicago, Univ. Press.

Lowe, P. (16r2). A Discourse of the Whole Art of Chyrurgerie. 2nd ed. London, Purfoot.

MAcKenzie, F. W. (1853). 'The nature and proximate cause of phlegmasia dolens.' Med. chir. Trans., $\mathrm{xxxv1,} \mathbf{1 6 9 .}$

MaSweeney, G. J. (1949). 'Puerperal Sepsis', pp. 21-33, in Rotunda Hospital Bicentenary. Trans. intern. Congr. Obstet. Gynaecol., 1947. Dublin, Parkside Press.

MAJOR, R. H. (1954). A History of Medicine. Vol. I. Oxford, Blackwell.

MALPIGHI, M. (1666). De viscerum structura, accedit dissertatio de polypo cordis. Bononiae, Montij.

MAURIGEAU, F. (1712). Traité des maladies des femmes grosses et des celles qui sont accouchees. 5 th ed. 1 , 446. Paris, Foucault.

Mesnard, J. (1753). Le guide des accoucheurs. Paris, de Bure.

Morgan, T. (1725). Philosophical Principles of Medicine. London, Darby and Browne.

Nicaise, E. (1893). Chirurgié de Maître Henri de Mondeville composée de 1306 d 1320. Paris, Alcan.

Puzos, N. (1 759). Traite des Accouchemens. Paris, Deslandes.

Quincy, J. (1 722). Lexicon Physico-Medicum. 2nd ed. London, Bell, Taylor and Osborn.

RAmazzini, B. (1 705). A Treatise of the Diseases of Tradesmen. London, Bell et al.

Roxitansky, C. (1852). Pathological Anatomy, Iv, 336. London, Sydenham Soc.

RUYsch, F. (1 707). Thesaurus Anatomicus. Septimus, No. xxxix. Amsterdam, Wolters.

Sauvages, F. B. De (1 768). Nosologia Methodica. Amsterdam, Tournes.

Smenlie, W. (1764). A Collection of Cases and Observations in Midwifery. Vol. II, 3rd ed. London, Wilson.

Thомpson, D'A. W. (1910). The Works of Aristotle. Oxford, Clarendon Press.

TRYE, C. B. (1 792). An essay on the swelling of the lower extremities incident to lying-in women. London, Murray.

VeIth, I. (1949). The Yellow Emperor's Classic of Internal Medicine. Baltimore, Williams and Wilkins.

VICARy, T. (1636). The Englishman's Treasure. London, Alsop and Fawcet.

Virchow, R. (1860). Cellular Pathology. London, Churchill.

White, G. (1784). An Inquiry into the Nature and Cause of the Swelling in one or both of the Lower Extremities, which sometimes happens to Lying-in Women. Warrington.

Wiseman, R. (1676). Severall Chirurgicall Treatises. London, Royston and Took. 